\title{
Human movements: immigrants and asylum seekers. Two sides of the same coin
}

\author{
Iuliana MIHAI, Isabel NOVO-CORTI \\ University of A Coruña, Spain
}

\begin{abstract}
Aim: Millions of people are displaced globally, as refugees, asylum seekers or migrants. Although, at a first glance, crisis and conflicts are considered the main trigger for these movements, the migration challenge may have different roots: demographic trends, poverty, the globalization of communication, etc. The present article is an introduction to the main concepts and terminology regarding migration and it links the migration with actual labor problems within the EU.
\end{abstract}

Design: The article shows how migration terminology is reflected in the EU migration policy and how migration policy affects labor policy and vice versa. The article is to be considered a state of the art or methanalysis and explains the concepts: in-migration, out-migration, refugees, asylum-seekers. In addition, it draws attention to controversies regarding the use of concepts: illegal migration, irregular migration and return migration.

Conclusions: The article presents eight main economic theories of migration. Five of them have as subject of analysis the determinants of migration and the other three have the subject of analysis the perpetuation of migration. Some of the main theories analyzed here are the neoclassical theory of migration, the human capital theory of migration, the new economics theory of migration, world system theory, network theory, migration systems theory.

Originality: The article demonstrates the fact that neither of these economic theories/models explain adequately the actual determinants of migration and it proposes a new model focused more on the transdisciplinary effects of human movements.

Keywords: migration, crisis, development, asylum seekers, labor market policies JEL: J015, J61, J15

Correspondence address: Iuliana MIHAI, Isabel NOVO-CORTI, University of A Coruna, Faculty of Economics And Business Strategy, Campus Elviña S/N - 15071a Coruña. Spain E-mail: iuliana.mihai@udc.es

Received: 13,07.2018, Revised: 09.12.2018, Accepted: 11.12.2018

doi: http://dx.doi.org/10.29015/cerem.755 
"Even if we are now moving away from crisis mode, it is evident that migration will remain a challenge for a generation of Europeans. Europe urgently needs to equip itself with futureproof means of managing migration responsibly and fairly".

European Commission President Jean-Claude Juncker

\section{Introduction}

As the German Chancellor Angela Merkel warned in her speech ahead the EU summit (Shubert et al. 2018) "Migration could be a 'make or break' issue for the European Union". The migration and refugee crisis links several aspects, the increased migration from Middle East and North Africa, aging population in EU developed countries, the EU relations with Turkey, the controversies regarding human rights and the issue of humanitarian action. Despite the above-mentioned issues, Europe is dealing with a lingering debt crisis, a rise of European populism, an escalating trade war with the United Stated and the negotiations for Brexit.

The recent news as: "La llegada de inmigrantes alcanza su máximo desde 2008" (Martin 2018), "Death threats, despair and deportations: Three years on the front lines of Europe's migration crisis" (Vonberg 2018) emphasize the characteristics of the present migrant and refugee crisis in Europe.

Furthermore, the regional mass-media news titles, such as: "Central European countries to skip migration summit as EU tries to work out refugee issue" (Kosztolanyi, Cullen 2018), "Italian interior minister tells rescue ship to "bring migrants to the Netherlands" (Mezzofiore 2018), "Hungary's 'Stop Soros' law makes it illegal to help migrants" (Vonberg, Clarke 2018), stress out the political consequences and the tensions between EU member states created by this crisis.

Given the above-mentioned problems, the aim of the present article is to show how migration terminology is reflected in the EU migration policy and how migration policy affects labor policy. Other secondary objectives is to describe the main economic theories of migration and several models and methods that analyzed the relationship between migration and development. The design of the present article is mainly descriptive and is based on scientific works, articles, reports, etc. of famous specialists of regional and international organizations. 
The article faces also several limitations: firstly, is overly descriptive, secondly, the concepts associated with the terminology specific for asylum seekers is somehow included in the over role debate about migrants. Therefore, some may say that this article does not say much about asylum seekers. On the other side, a big advantage of reading this article stays in its utility for those who are just beginning to study issues related to migration and development. The following lines are a short resume of the subchapters.

The first subchapter is introducing the main concepts and terminology regarding migration, such as: internal migration, international migration, refugee and asylum seeker etc. and the tensions and controversies between EU member states that started with 2015 crisis. The following subchapter brings the answers to two main questions regarding the development of international migration and international trade: Why haven't international institutions developed to deal with world migration like those that have developed to deal with world trade? and How should the immigration policies in the host countries should be? and an analysis of the driven forces of migration, especially the economic and the demographic ones.

The third subchapter is a review of the main economic theories of migration, emphasizing the main variables and the main critiques of each of these theories. There are presented in total eight main theories of migration, five of them have as subject of analysis the determinants of migration and the other three have the subject of analysis the perpetuation of migration. The theories are the neoclassical theory of migration, the human capital theory of migration, the new economics theory of migration, world system theory, dual labor market theory, network theory, migration systems theory and transnational theory. All the information from this subchapter is concentrated in a table at the end of it.

The fourth subchapter presents two approaches regarding the methods and the models studying migration and development: the deterministic perspective and the stochastic (probabilistic) perspective, with the corresponding examples for each of them. Finally, the last one presents the advantages of circular migration and several market labor restrictions. Lastly, the article is ending with a set of conclusions and policy recommendations. 


\section{Conceptualizing migration and presenting recent data}

This subchapter offers an overview over the main concepts related to migration and several observations about the refugee crisis from 2015.

Firstly, it is necessary to define the main concepts that stand at the base of this paper. Therefore, the first concept is migration understood as the movement of a person or a group of persons within a country (internal migration) or across an international border (international migration). Regarding the former, there are two types of migration: in-migration, the permanent movement of persons into a new area, and out-migration, the permanent movement of people out of their origin area. Regarding the international migration, there are emigration, the process of departing from one country to another, and immigration, the process by which non-nationals enter into another country (International Organization for Migration 2011).

As the actual crisis is not referring only at immigrants, but also at refugees and asylum seekers, it has to be distinguished between these two terms. According to Convention relating to the Status of Refugees, Art. 1 A(2) a refugee is a person who "owing to well-founded fear of being persecuted for reasons of race, religion, nationality, membership of a particular social group or political opinion, is outside the country of his nationality and is unable or, owing to such fear, is unwilling to avail himself of the protection of that country; or who, not having a nationality and being outside the country of his former habitual residence as a result of such events, is unable or, owing to such fear, is unwilling to return to it" (United Nations 1951) while an asylum seeker is a person who applies for asylum in order to be acknowledged as a refugee, but it does not have this status yet (UNHCR 2018).

Furthermore, it should be taken into account several observations about the refugee crisis from 2015: the migratory flows from Middle East are a part of a new historical period in terms of international migratory pressures. One of the most contributing factors of this fact include the persistence of significant inequalities regarding salaries between countries and the demographic dynamic of the developed world (the increasing aging population) and of the developing world (with more equilibrated cohorts of population). In addition, another attracting factor of migration regards the consumption lifestyles in developed world that are spread 
rapidly in developing world, alongside with the diminishing costs of displacements and transportation (Alonso 2011).

The 2015 crisis continues in present creating more animosities, debates and controversies between EU states. As Figure 1 shows, in 2018 there were eight routes of entries: eastern border, the majority of them coming from Vietnam, Russia, Turkey, Ukraine and Iraq, the second route is the Western Balkan, the top nationalities being Pakistan, Afghanistan, Syria and Kososo. The third route is Eastern Mediterranean, the majority of them coming from Syria, Iraq, Turkey, Afghanistan and Pakistan. Furthermore, there is a circular route between Albania and Greece, and another route from Apulia and Calabria. Through the Central Mediterranean route, the majority of migrants have Tunisian and Eritrean nationalities. Thorough the western African route the majority of irregular migrants came from Morocco and through the last route, Western Mediterranean, came migrants with Moroccan and Guinean nationalities (Frontex: European Agency for the Management of Operational Cooperation at the External Borders of the Member States of the European Union 2018).

We should not look only at the numbers, but also at the demographic characteristics of the immigrants. As such, in an IMF report about the economic consequences of the refugee surge in Europe it is stated those immigrants from the main countries of origin of the 2015 wave of asylum seekers are on average less educated than the native population or other immigrants. In addition, FMI reports that the majority of them are twice as likely to have a lower secondary education or less. Furthermore, it is interesting to see that the immigrants born in other countries, EU countries with advanced economies, tend to have better educational outcomes compared to native-born population. In addition, it is interesting to note that the 2015 wave of asylum seekers was better educated than past immigrants from the same origin countries. For example, in Germany $21 \%$ of Syrian asylum seekers who arrived in 2013-2014 reported having tertiary education (International Monetary Fund 2016).

If the situation regarding the migration outside the European Union poses several problems, the intra-migration within the European Union raises also s couple of problems. These problems are intensifying the tensions between the European 
countries and leading to exit decisions as UK did, skepticism and hesitations (German and Dutch politicians) and the support for new controversial EU rules (such as "posted workers", rule backed by French politicians) which may create unequal treatment with nationals regarding the access to employment. These problems have been the subject of analysis not only in the media (The Economist 2016), but also in the academic field. For example, a recent IMF report (Atoyan et al. 2016) found out that the home countries of emigrants have been most hurt, especially post-communist emigration from East-European countries strained their growth, their public finances and accentuated the demographic problems.

\section{Figure 1. Main entry routes}

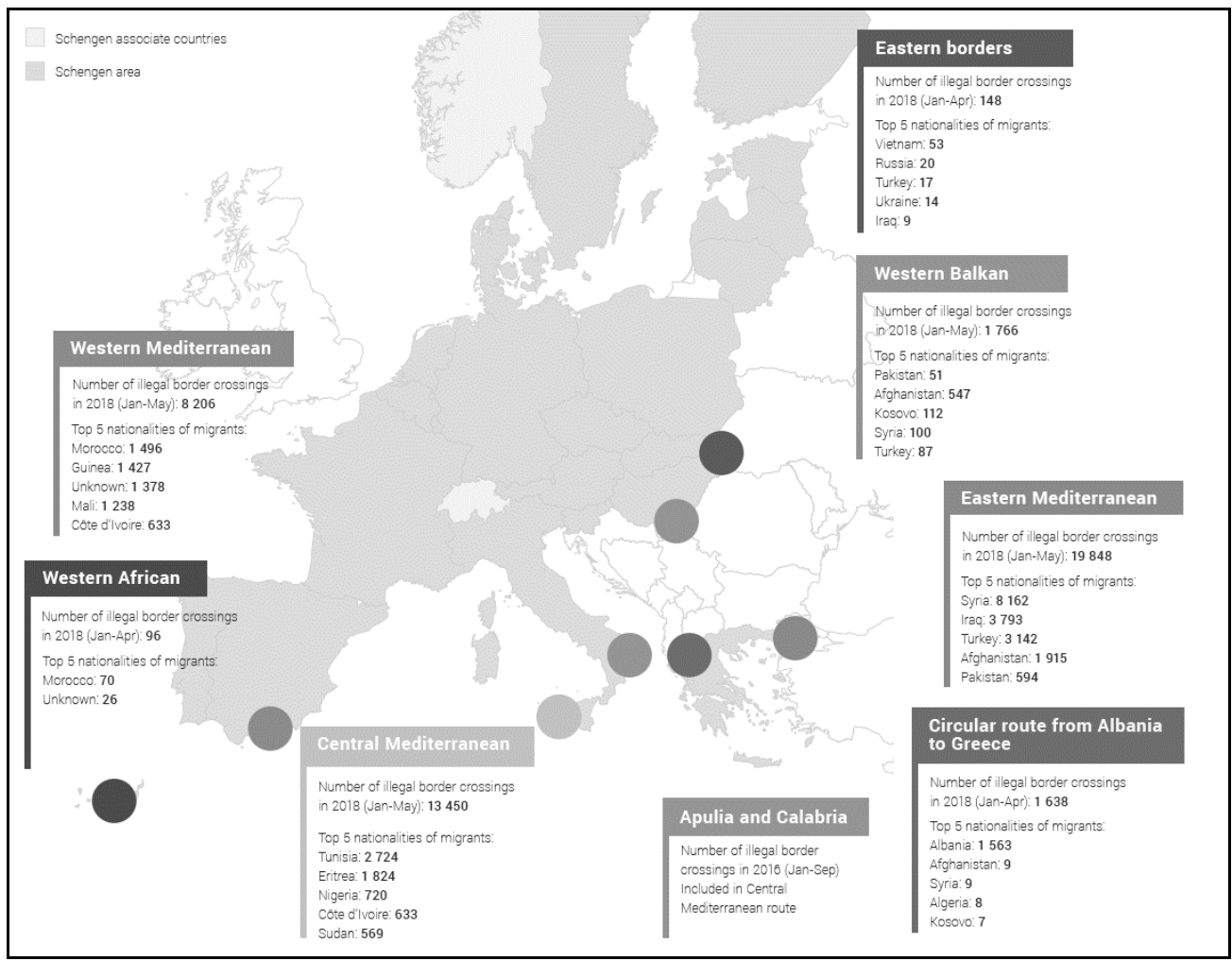

Source: FRAN and JORA data, 6 June 2018. 


\section{A short introduction of international migration history}

The early waves of free migration involved family groups from the moredeveloped European economies, usually farmers and artisans. Hatton and Williamson (1994) analyze the driven forces of migration: the economic and demographic factors. More specifically, the fall in transport costs in mid-nineteenth century which made migration feasible for a widening pool of potential migrants and, secondly, the rising income in the sending countries which expanded the pool of immigrants including several poor groups. Regarding the demographic factors, it is emphasized how the demographic transition from the entire nineteenth century and the friends-and-relative effect have created big cohorts of young people prepared to migrate to developed countries.

Hatton and Williamson (1994) speak about two migration environments: the one that was formed by the Atlantic economy and the second one that was formed by the rest of the world. In the southern half of the Atlantic economy free mass migration delayed three or four decades and in the other parts of the world they delayed for almost a century. Regarding the Atlantic economy, the peak of mass migration is considered 1913. This period was followed by restrictive policy, caused by several factors: war, depression, the increased flows of poor migrants and the relative unskilled labor scarcity.

Hatton and Williamson compare the periods of mass migrations before the First World War and those since the Second World War and they found several similarities and differences. The main similarities are the following: that the mass migration in both cases grew and its scope expanded; in both periods, the migration direction was from the poorer parts (but not too poor) to the richer parts of the world. Another common feature of these two periods is the widening development gap between high-wage host countries and low-wage source countries. Furthermore, the gap in labor market performances between new and old immigrants contributed more and more to the quality gap between immigrants and natives in host countries. This gap may be a result of the shift from positive to negative selection of immigrants, and the changing mix of source countries (from those with higher levels of education and skills to those with lower levels of education and skills). This gap 
has widened greater and greater in both analyzed periods, but has become much larger in the half century, after 1870.

The main differences are also important: the main destinations for European emigrants in the late nineteenth century were the Americas and the Australasia while in the late twentieth century Europe becomes a destination for immigrants, while South and Central America did the opposite. The main difference between the two global centuries lies in immigration policy. While, in the nineteenth century host countries encouraged immigration, in the 1920s these countries imposed an antiimmigrant policy based on quotas. Since 1970s, the policy has changed also its goals: it became much less discriminatory (while the policies before 1970s restricted immigrants to a key source, the ones after 1970s admitted immigrants from everywhere in the world). Secondly, the policy has become more skill selective: from low-skilled guest workers to high skilled permanent immigrants (Hatton, Williamson 1994).

Furthermore, we can observe a policy difference between trade and migration policy: the immigration policy was more pro-global than trade policy in the first global century, while the reverse is applied in the case of the second global century. According to the simple theory, within a simple two good two factor model, migration and trade are perfect substitutes. Therefore, restrictions on trade and restrictions on migration should go hand in hand. It may be considered that, despite several factors that may explain this paradox, such as: the spread of democracy, the decline of empires, the changing social norms and attitudes toward immigrants, politics etc., three main factors may explain this paradox.

The first factor is related to discrimination and the labor market; it is emphasized that at the start of the first global century, European emigration was conditioned by migration costs and poverty trap, while in last years of this century the immigration from the poorer parts of the Europe increased very much and that was the moment when the debate about immigrant restrictions and exclusion started.

The second one is about the government revenues, social expenditures and the fiscal impacts of immigration and trade. In the first global century, the fiscal impact of immigration mattered less than the fiscal impacts in the second global century because in the first case the immigration has not brought significant fiscal costs. 
Therefore, for the period before 1914, high tariffs and low immigration restrictions coexisted for fiscal reasons. By contrast, from 1930s to 1970s the social services and the welfare state expanded very much, creating the need to control social spending. Therefore, in the second global century, low tariffs and high immigration restrictions coexisted for fiscal reasons.

The third factor is the presence or the absence of international cooperation; in this regard the GATT organization can be compared with the IOM organization, the first one as an example of international cooperation which achieved to reduce tariff levels since 1948 while the second, despite being created in 1951, it had not established such accomplishments regarding migration as those of GATT. Therefore, IOM should reform their goals in order to establish the architecture for international cooperation on migration issues.

Therefore, we will have to find the answer to the following question: Why haven't international institutions developed to deal with world migration like those that have developed to deal with world trade? We may begin by comparing the principals upon which modern trade was built: reciprocity, nondiscrimination and fair treatment. It is well-known the fact that these principals stood at the basis for bilateral agreements in nineteenth century and for the multilateral ones in the following periods of time. In theory, these arguments for free trade are basically the same as for free migration. But it seems that in reality, the argument of reciprocity is different in the case of migration because migration is more like a one-way street, being more beneficial for the receiving country. Furthermore, if we look also at the bilateral migration balances and the trade ones, we will observe that the migration ones are far more unequal than the second ones. It is important to note that this idea does not imply that other forms of limited cooperation with significant migration flows in both directions does not exist, such as The European Union's Schengen Convention, Nordic Common Labor Market of 1954, ECOWAS, etc.

Another question arise: How should the immigration policies in the host countries should be? The answer includes three main immigration policy options: a selective immigration policy, which may contain a points system; the second one consists in taxing the immigrants, such as: a tax on employers or schemes through which migrants would only pay if their earnings exceed some threshold, etc. The last 
one are temporary work schemes, but this one may discourage the immigrant acquisition of human capital during their temporary period and become gateways to permanent migration for those who want to come.

\section{Economic theories of migration}

There are in total eight main theories of migration, five of them have as subject of analysis the determinants of migration and the other three have the subject of analysis the perpetuation of migration. The theories are: the neoclassical theory of migration, the human capital theory of migration, the new economics theory of migration, world system theory, dual labor market theory, network theory, migration systems theory and transnational theory. Many of these theories consider as the main determinant of migration the wage difference between the country of origin and destination country. For example, the neoclassical theory of migration, human capital theory of migration and new economics theory of migration analyze the main determinates of migration and consider as the main variable wages and income differential/income distribution.

Neoclassical theory defines migration as the result of labor differences across markets. The basic model was originally developed by Lewis (1954) and Harris and Todaro (1970) and the central argument of this approach focuses on wages: the driven factors of migration are geographic differences in labor supply and demand and the wage differences between countries rich in labor and countries rich in capital. The model predicts a linear relationship between wage discrepancies and migration flows and, in the extended neoclassical models, the expected, rather than actual earnings, determine migration.

As time went on, different studies adjusted the model in distinctive ways. These studies proved that the linear relationship between migration and wage differential does not hold and have given greater importance to the level of a country income. Also, have taken into account the cost associated with migration and have demonstrated that it is not the poorest individuals who migrate, nor the poorest 
countries which send the most labor (De Haas 2010; Dustmann et al. 2003; Massey et al. 1999).

At the micro level, the equivalent of the neoclassical model is human capital theory of migration. Introduced by Sjaastad (1962), the theory upgrades the neoclassical model by incorporating the socio-demographic characteristics of a person (skill, age, occupation, labor market status, preferences, expectations, etc.) as an important deterministic factor of migration. This theory of T.K. Bauer and Zimmermann (Bauer, Zimmermann 1999) demonstrated that migration levels decrease with age and increase with education level, therefore migrants tend to be more educated.

Related to neoclassical theory is the push-pull framework, a framework as a mirror image of each other, where the main economic determinants of migration are the result of the interaction between factors associated with the origin area (repelling or push factors) and the factors associates with the destination area (attracting factors or pull factors).

The main critiques of the neoclassical theory are ignoring market imperfections, is a historical and static, ignores the importance of policies and politics and it homogenizes migrants and migrant societies. The main critique regarding the human capital theory is that it presents migration in an overly optimistic perspective, given the fact that migration is not always a voluntary process to maximize gains. The wide dissatisfaction with the simplistic perspective of the neoclassical explanations lead to the emergence of a new theoretical perspective of migration.

The new economics theory of migration shifts the attention from isolated individual actors to families or households, implying that migrant decisions are not based primarily on individual decisions in order to maximize the utility, but rather is a household response to income risk and to the failures of different types of markets, such as: labor market, credit market and insurance market. Therefore, the new economics theory of migration explains the migration decision by taking into consideration other factors despite wage differentials, responses to relative deprivation. Stark $(1991,2003)$ introduces several concepts to explain this new approach: on the one hand, the term relative deprivation, a household status performing worse relative to other households; on the other hand, there are risk- 
aversion and risk-minimization of household income. Within this model, remittances play an important role because it directly supports the household interconnectedness. Along with the limited applicability, this theory is too future orientated and has been criticized for sending-side bias (Faist 2000).

World systems theory is a historical-structural approach to migration, which connects the determinants of migration to structural change in world markets and defines migration as a result of globalization, the interdependence of economies and the emergence of new forms of production (Massey et al. 1993; Sassen 1990; Silver 2003). World system theorists explain the increased waves of migration through several processes: the expansion of export manufacturing, foreign direct investment flows from developed countries to developing countries, capital mobility, political and economic inequalities.

The theory faces several critiques for the fact that individuals do not truly have a free choice in making migration decisions (because a migration decision is seen more in deterministic form, as an outcome of wider structural processes) and the framework is too descriptive.

Based on the same idea of structural change in the economy, the dual labor market theory explains migration flows only using the demand side. Developed by Piore (1979) this theory supports the idea that the immigration is caused only by pull factors in the receiving countries, more specifically the labor demands for foreign workers. It is argued that this demand has been caused primarily by structural inflation: in developed countries, the cost of employers to attract low-skilled workers is more than the cost of their wages, because as the wages will increase at the bottom level, it will create pressures from workers at different levels to increase their wages too. Therefore, employers must increase the wages proportionally according to job hierarchy in order to confine with their expectations. Thus, is more expensive to hire native workers by increasing entry wages than to hire migrant workers who are satisfied with the low wages. This theory also faces several criticisms: excludes sending countries, overemphasizes formal recruitment practices, does not bring explanations for differential immigration rates in countries with similar economic structures, etc. 
Shifting the attention from determinants of migration to factors that perpetuate migration in time, the network theory of migration comes along. This theory explains why migration continues even if wage differentials cease to exist and it explains why migration patterns are not distributed evenly across countries. Network theory is closely linked with another perspective, called migration systems theory. Introduced by Mabogunje (1970) this theory`s main assumption is that migration changes the socio-cultural, economic and institutional conditions in both sending and receiving countries and develop a complex developmental space specific for migration processes. Although these two theories are very similar, there are also several specific differences: migration systems theory has its roots in geography, and migration network theory has its roots in sociology and anthropology; another difference is that network theory emphasizes on the role of personal relations between migrants and non-migrants, and migration systems theory stresses the structures created by migration at societal level.

Another perspective, which combines features of network theory and the systems one, is cumulative causation theory put forth by Myrdal (1957) and further developed by Massey et al. (1993). The main hypothesis is that each act of migration influences the socio-economic context within which the later migration decisions are made; in such a way, that migration tends to determine more migration. Within the cumulative theory, were treated systematically six socio-economic factors that are affected by migration: the first one is the distribution of income: people migrate in order to improve their absolute income, but also their income relative to other persons from the same reference group. Seeing other families improving their level of income through migration into foreign labor markets, induce others to migrate in order to raise their levels of income and the increasing number of people who migrate will exacerbate de level of income inequality in area of origin.

The distribution of land (this is applied especially in rural communities) says Massey et al. (1993: 452-454) refers at the fact that the purchased farmland of the migrants is not cultivated as much as the ones of the non-migrants as a result of the foreign wage labor which is more profitable than the local one. This fact reduces the demand for local farm labor and increases the pressures for migration and the process continues inducing more and more people to migrate. Regarding the culture 
of migration, the forth factor, stresses the fact that migration produces changes at the level of preferences and values among those who migrate in another country for a short/long period of time; as migration grows, all the values and perceptions are changed within a community increasing the desire for future migration.

The regional distribution of human capital emphasis that migration is a selective process because, initially at least, skilled and productive migrants leave behind their places of origin and settle down in the receiving countries; the continuum process of sustained migration determines a reduction of human capital in the sending regions and an accumulation of human capital in the receiving regions and this distribution affects the level of productivity, being increased in the latter case and decreased in the former case. The sixth factor, the social meaning of work changes causing a stigmatization of certain types of jobs considered inappropriate for natives.

Continuing the same line of reasoning, the above concepts have been further developed into the theory of transnational migration, a theory that emphasizes more means of migrant insertion and active participation of migrants in the origin and the host countries. The transnational social spaces are the result of the increased migration movements and the changes within the strategies adopted by international business companies Pries (Pries 2013). Faist (2006) identifies four types of transnational spaces: small groups, as households and kinship systems; issue networks, such as business networks, scientific networks, immigrants and citizenship associations; transnational communities such as village communities, religious groups and diasporas and transnational organizations as Red Cross, Amnesty International, Greenpeace. A synthesis of the main theories is presented in the below table, with an emphasis on variables and critiques. 


\section{HUMAN MOVEMENTS: IMMIGRANTS AND ASYLUM SEEKERS.}

\section{Table 1. Main theories}

\begin{tabular}{|c|c|c|c|}
\hline Theory & $\begin{array}{l}\text { Subject of } \\
\text { Analysis }\end{array}$ & Variables & Critiques \\
\hline $\begin{array}{l}\text { Neoclassical theory } \\
\text { of migration }\end{array}$ & $\begin{array}{l}\text { Determinant } \\
\text { s of } \\
\text { migration }\end{array}$ & $\begin{array}{l}\text { Wage and income } \\
\text { differentials } \\
\text { - } \quad \text { Probability of } \\
\text { Employment }\end{array}$ & $\begin{array}{l}\text { - } \\
\text { politics and policies } \\
\text { - } \quad \text { Ignores market } \\
\text { imperfections } \\
\text { - Unable to explain } \\
\text { differential migration } \\
\text { - } \quad \text { Homogenization of } \\
\text { migrants and societies. }\end{array}$ \\
\hline $\begin{array}{l}\text { Human capital } \\
\text { theory of migration }\end{array}$ & & $\begin{array}{l}\text { - Wages, economic } \\
\text { benefits affected by individual } \\
\text { characteristics }\end{array}$ & $\begin{array}{l}\text { - Overly optimistic } \\
\text { perspective }\end{array}$ \\
\hline $\begin{array}{l}\text { New economics } \\
\text { theory of migration }\end{array}$ & & $\begin{array}{l}\text { Wages and income } \\
\text { distribution (relative deprivation) } \\
\text { Institutional failures - } \\
\text { credit } \\
\text { market, labor market } \\
\text { deficiencies }\end{array}$ & $\begin{array}{l}\text { Critique of the } \\
\text { neoclassical theory rather than a } \\
\text { theory in its own } \\
\text { - } \quad \text { Limited applicability }\end{array}$ \\
\hline $\begin{array}{l}\text { World system } \\
\text { theory (historical- } \\
\text { structural } \\
\text { approaches) }\end{array}$ & & $\begin{array}{l}\text { - Structural changes } \\
\text { induced by the flow of capital }\end{array}$ & $\begin{array}{l}\text { - Only applicable at the } \\
\text { global level }\end{array}$ \\
\hline $\begin{array}{l}\text { Dual labor market } \\
\text { theory }\end{array}$ & & $\begin{array}{l}\text { - } \\
\text { - } \\
\text { markets } \\
\text { - } \\
\text { - } \\
\text { polifurcation of labor } \\
\text { policies and } \\
\text { State immigration } \\
\text { recruitment efforts }\end{array}$ & $\begin{array}{l}\text { Excludes push factors, } \\
\text { formal recruitment } \\
\text { practices overemphasized. } \\
\text { - Unable to account for } \\
\text { differential immigration rates in } \\
\text { different } \\
\text { advanced economies with similar } \\
\text { economic structures. }\end{array}$ \\
\hline Network theory & $\begin{array}{l}\text { Perpetuation } \\
\text { of migration } \\
\text { and/or } \\
\text { directionalit } \\
\text { y of flows }\end{array}$ & Networks, diaspora & $\begin{array}{l}\text { - It is not a theory, but } \\
\text { rather a conceptual framework }\end{array}$ \\
\hline $\begin{array}{l}\text { Migration systems } \\
\text { theory }\end{array}$ & & Developmental space & Purely descriptive \\
\hline $\begin{array}{l}\text { Transnational } \\
\text { migration }\end{array}$ & & $\begin{array}{ll}- & \text { Transnational social } \\
\text { spaces } & \end{array}$ & $\begin{array}{l}\text { - Novelty of the } \\
\text { concepts has been questioned }\end{array}$ \\
\hline
\end{tabular}

Source: Kurekova (2011: 6-9). 


\section{Migration forecasting methods and models}

There are two approaches regarding the methods and the models studying migration and development: the deterministic perspective and the stochastic (probabilistic) perspective. A model, in comparison with a theory, is hypothetical, is related to a particular reality and is has a higher degree of flexibility.

Within the deterministic methods and models in migration prediction, we can find five models: judgmental migration scenarios, the Delphi method, 'migration potential' assessment surveys, macro-level mathematical models in demography and demo-economic modelling attempts. Judgmental scenarios are used usually in demographic forecasting and describe future trajectories of particular characteristics of population change (fertility, mortality, migration). Based on qualitative and quantitative argumentation, the scenarios have to be coherent with the underlying assumptions behind them and by using the what-if approach, shows the demographic consequences of distinctive processes. The study of Sir William Petty (1966) concerning the future growth of the City of London, the forecast of the East-West migration in Europe after the EU enlargement in the research of Layard et al. (1992), the gravity model of net migration between ten Central and Eastern European countries in the works of Alvarez-Plata, Brücker, and Siliverstovs (2003) are some of the examples where the judgmental scenarios were implemented.

The Delphi method is based on a group judgment by carrying out surveys among experts from various countries and fields of expertise. The exchange of knowledge is realized in subsequent rounds and the final output is created from the aggregation of all the individual suggestions. As examples which used this method are: the study of Drbohlav (1996) in estimating the expected East-West migration flows in Europe, the study of Azrael, Brukoff, and Shkolnikov (1992) in estimating the emigration from the former USSR in the period 1992-1997, T. Bauer (1999) attempt to gather information on future migration flows from Central to Western Europe.

"Migration potential" assessment surveys, as it is stated in the name, are typically based on questionnaires filled in by representative random sample of respondents, who are asked to answer if they consider undertaking migration, the 
reasons, the context, etc. Examples of such studies regarding the East-West flows in Europe are presented in IOM (IOM 1998) reports.

The mathematical models of migration stem from two different fields of study: demography (the impact between population distributions and migration) and human geography (the spatial outcomes of the redistribution of migrants). The deterministic nature of these models (the cohort-component model, population accounting models, multi-regional model, multi-level model MULTIPOLES) stems from their algebraic formulations and from the dominant forecasting practices in demography.

The demo-economic modelling attempts are models that combine population and economic aspects of social development. An interesting example using this modelling attempt is the recent study of Fachin (2002: 10-15). Their model, called the IDEM combines a multi-regional cohort-component model of population dynamics with an economic input-output analysis. In this model, migration links demography with economic aspects: labor supply, productivity, and the focus was on the internal migration from Italy.

Regarding the probabilistic migration forecasts, there are six types of models as follows: the Markovian models; the micro-level methods, other attempts combining micro and macro perspective, the econometric forecasts, the stochastic forecasts of migration time series and the Bayesian models. Regarding the use of Markovian models, it has to be said that stems from the tradition of human geography, it was very popular in 1960's and 1970's and it emphasized the spatial redistribution of population through migration. Regarding the micro-level methods: event-history and ethno-survey are traditional analytical techniques used initially in demography and it have two main drawbacks: it is cost and labor consuming and the sample used does not provide representative results.

Combining micro and macro perspectives in population modelling, Courgeau (1992) observed that both methodologies are complementary: the individual and the aggregate characteristics are introduced, the macro-level variables providing the exogenous context for the analysis of individual characteristics within an eventhistory approach. The econometric forecasts of international migration predict migration and verify particular economic theories based on empirical data. The boom in using econometric models dates back to the 1990`s and analyzed the 
population flows as a result of the EU enlargement. The main models used within this category are the Gaussian autoregressive process and generalized linear models.

The stochastic forecasts of migration are based on the analysis and extrapolation of time series and the most common methodologies applied are autoregressive integrated moving average models and vector autoregressive modelling. The Bayesian models are scarce, the majority of them being based on Poisson regression.

\section{Labor market restrictions and circular migration}

Gutirrez (2016) studied the development and the characteristics of the two dimensions of precariousness: insecurity (measured by forms of atypical employment: temporary work, part-time work and self-employment) and poverty (measured by the share of low-wages earners) and the effects on the labor market of the EU 15 countries, before and after the crisis from 2008. The results show that the work conditions are similar across countries with similar levels of precariousness. Also, the results show that there are three labor market models, according to flexibilization policies. These is the model encountered in the southern countries (Spain, Greece, Italy and Portugal) with high levels of security and poverty; countries with a more deregulated labor market: Germany, Ireland, the Netherlands and the United Kingdom which presents moderate levels of insecurity and high levels of poverty and thirdly, the Nordic countries, together with Belgium and France which have moderate levels of both insecurity and poverty.

Regarding the restrictions on the labor market, Benton et al. (2014) assesses the factors that contribute to the slow progress in the field of labor market integration and it is based on 12 case studies from six European countries: The Czech Republic, France, Germany, Spain, Sweden and the United Kingdom and interviews with more than 50 experts and policy-makers. The report begins with the factors that explain why immigrants with medium skilled work remain stuck in low-skilled jobs. Afterwards, the report analyses how different policies, such as integration, employment and training plans to respond to this challenges. 
The main barriers to enter middle skilled jobs are insufficient skills and experience for available jobs, unrecognized qualifications, and difficulties navigating local labor markets, formal and informal obstacles to employment. Regarding the policies to support labor market integration, the section has been classified into three areas in which these kinds of policies are concentrated: integration policies for new arrivals, employment policies and vocational and language training. It was interesting to observe that employment officials are not familiar with important integration concepts, such as credential recognition. In addition, it can be observed the lack of coherence of integration policies overall. For example, in France and Sweden, the new arrivals are required to reach a certain levels of language proficiency before the assessment of their skills.

Another interesting observation was that many public employment services lack a systematic approach in order to identify the needs of language learners and people with foreign qualifications. From all the mentioned countries, only Germany and Sweden highlighted the issue of qualifications as an employment barrier for new arrivals.

Given the problems created by the actual migrant crisis, a solution may be circular migration. This type of migration represents the temporary and repetitive movement of a migrant worker between home and host countries, usually for employment purposes. Based on several case studies, mainly from Asia and Africa, the Agunias's (2006) report analyzes the impact of circular migration on development and focuses on policies that encourage circular migration.

It is interesting to observe that this concept is viewed as a triple-win scenario, providing benefits for the sending countries, the receiving countries and the migrants themselves. How each of them benefits from circular migration, is the subject of study in this report. Developed countries allow migrants to fill the labor shortages for a specific period of time. On the other side, developing countries benefit because migrants will return in the origin countries after a while, therefore the developing countries will not lose their skilled workers. Furthermore, the migrants themselves benefit in at least two ways: an increase in wages and an increase in the skills they learn abroad. In other words, we can say that the benefits appear in three forms: financial capital through remittances, human capital and social capital. 
On the other side, circular migration also presents several costs, for examples: temporary brain-drain, restrictions on freedom because recruitment may involve false promises and deception, circular migration may also perpetuate existing inequalities and may create gender issues because in numerous developing countries women are less likely to participate in circular migration. Another cost of circular migration is connected with health issues, many migrants being vulnerable to contract sexually transmitted diseases.

All the above-mentioned advantages and disadvantages of circular migration have been emphasized also by Zimmermann (2014). He brings arguments of the counter-productivity of restricting the labor migration. The main examples used which argue that immigration restrictions have negative outcomes are: the case of Spain after 2004, in Germany with the end of guest worker program following the 1973 oil crisis, also the German failure to benefit from the migration flows determined by the EU enlargement in 2004 and 2007.

\section{Conclusions and recommendations}

Papademitriou and Benton's (Papademitriou et al. 2016) report studied the challenges and the policy approach regarding a better integration of the new immigrants in Europe. When referring to the labor market integration, they emphasize several facts: that, on average, foreign-born migrants in European Union compared to the natives have smaller employment rate, higher underemployment and low-quality jobs; also, the women employment and activity rate are much lower than those of men are. When compared to other countries, such as Canada or United States, the employment rate in European Union is lower for foreign-born residents than for natives, and this situation may be explained by the fact that in European Union newcomers find employment after a quite long period. The variation between employment opportunities and labor market success is determined by education, route of entry, gander and the country of origin.

In addition, the report emphasized the changing labor markets and labor needs

the increased demand for more skilled workers and the increased automation in 
several areas such as: transportation, logistics, services and sale. In addition, jobs may be less connected to traditional career paths, many of future jobs being connected to freelance activities.

The relationship between economic growth and unemployment in European Union has been studied by Dimian, Begu, and Jablonsky (Dimian et al. 2017). More specifically, they studied the reasons why the unemployment rate in the European Union remained very high in the last years. It is demonstrated that economic growth rate has returned to an upward trend and the differences between EU countries in terms of growth are declining. Also, it has been demonstrated that young people are the most affected group by unemployment both in the short and in the long run. In addition, the lack of collaboration between companies and the education system deepen the mismatch between job requirements and worker qualifications. Begu et al. (2017) promotes the idea of green jobs due to their double role to absorb the unemployed and to promote sustainable economic growth.

Furthermore, those specific employment policies, such as fix-term or part-time contracts, reduce unemployment in the short-run. Thus, in the long-run there is a need also of training, retraining and lifelong learning. According to this study, it is considered that the main challenge in the developed countries is the mismatch between the job requirements and workers qualifications and the main challenge for the developing countries is the quality of jobs.

Although the study has a very good methodology using modern econometrics models, such as autoregressive distributed lag, it seems to reiterate the same ideas already demonstrated in the literature and also the above stated challenges which are supposed to correspond to this dichotomist classification are a little bit too simplistic.

After all the above debates and discussions about different models, theories, types of migration that better explains the determining factors of migration and migration impact on labor market, I believe in a new theory that explains not only the determinants of migration but also the perpetuation of migration. Actually, this new theory may be a combination of the new economic theory of migration and the network theory. This new theory will have as the main variables wages and income distribution, institutional failures and networks, through diasporas. 
Regarding the recommendations for a better integration of the new immigrants in Europe, we can suggest measures of early provision of relevant career advice: such as measures which encourage specialization, which improve networking and information-sharing mechanisms. Furthermore, we should take into account one more set of measures which aims at improving the opportunities for progression, such as: shifts from generic to work focused language instructions, more engagement from employers and unions in integration policies, online and mobile learning, language apps, etc.

\section{References}

Agunias D.R. (2006), From a zero-sum to a win-win scenario, „Literature Review on Circular Migration", Migration Policy Institute, Washington, DC.

Aiyar S., Barkbu B., Batini N., Berger H., Detragiache E., Dizioli A., Ebeke C., Lin H., Kaltani L., Sosa S., Spilimbergo A. (2016), The refugee surge in Europe. Economic challenges, „National Institute Economic Review", vol. 235 no. 1, pp. F16-F31.

Alonso J.A. (2011), International migration and development. A review in the light of the crisis UN, CDP Background Papers, United Nations, Department of Economics and Social Affairs.

Alvarez-Plata P., Brücker H., Siliverstovs B. (2003), Potential migration from Central and Eastern Europe into the EU-15. An update, European Commission, Directorate-General for Employment and Social Affairs, Unit A. 1, Brussels.

Atoyan M.R., Christiansen L.E., Dizioli A., Ebeke Ch., Ilahi N., Ilyina A., Mehrez G., Haonan Q., Raei F., Rhee A., Zakharova D. (2016), Emigration and its economic impact on Eastern Europe, International Monetary Fund Staff Discussion Note, July.

Azrael J.R., Brukoff P.A., Shkolnikov V.D. (1992), Prospective migration and emigration from the former USSR. A conference report, ,Slavic Review”, vol. 51 no. 2, pp. 322-331.

Bauer T.K., Zimmermann K.F. (1999), Assessment of possible migration pressure and its labour market impact following EU enlargement to Central and Eastern Europe, vol. 3, IZA Research Reports, Bonn.

Benton M., Sumption M., Alsvik K., Frantzke S., Kuptsch Ch., Papademetriou D.G. (2014), Aiming higher. Policies to get immigrants into middle-skilled work in Europe, Migration Policy Institute and International Labor Organization, Washington.

Courgeau D., Lelièvre E. (1992), Interrelations between first home-ownership, constitution of the family, and professional occupation in France, in: Demographic applications of event history analysis, Tussel J., Hankinson R., Tilton J. (eds.), Clarendon Press, Oxford, pp. 120-140. 


\section{HUMAN MOVEMENTS: IMMIGRANTS AND ASYLUM SEEKERS.}

De Haas H. (2010), Migration and development. A theoretical perspective, „International Migration Review", vol. 44 no.1, pp. 227-264.

Dimian G.C., Begu L.S., Jablonsky J. (2017), Unemployment and labour market mismatch in the European Union countries (Proceedings of Rijeka Faculty of Economics), „Journal of Economics and Business", vol. 35 no. 1, pp. 13-44.

Dustmann Ch., Casanova M., Fertig M., Preston I., Schmidt Ch.M. (2003), The impact of EU enlargement on migration flows, report, Research Development and Statistics Directorate, Home Office, London.

Fachin S., Venanzoni G. (2002), IDEM: An integrated demographic and economic model of Italy, paper presented at Paper for the 14th International Conference on Input-Output Techniques, Montreal, Canada.

Faist T. (2000), The volume and dynamics of international migration and transnational social spaces, Oxford University Press, Oxford.

Faist T. (2006), The transnational social spaces of migration, COMCAD Arbeitspapiere Working Papers no. 10, Bielefeld.

Frontex: European Agency for the Management of Operational Cooperation at the External Borders of the Member States of the European Union (2018), Migratory map, https://frontex.europa.eu/along-euborders/migratory-map/ [06.12 2018].

Gutiérrez-Barbarrusa T. (2016), The growth of precarious employment in Europe. Concepts, indicators and the effects of the global economic crisis, „International Labour Review”, vol. 155 no. 4, pp. 477508 .

Harris J.R., Todaro M.P. (1970), Migration, unemployment and development. A two-sector analysis, „The American Economic Review”, vol. 60 no. 1, pp. 126-142.

Hatton T.J., Williamson J.G. (1994), International migration and world development. A historical perspective, in: Economic aspects of international migration. A publication of the Egon-SohmenFoundation, Giersch H. (ed.), Springer, Berlin, Heidelberg, pp. 3-56.

International Organization for Migration (2011), Glossary on migration, „International Migration Law Series", no. 25, International Organization for Migration, Geneva.

Kosztolanyi B., Cullen S. (2018), Central European countries to skip migration summit as EU tries to work out refugee issue, CNN, https://edition.cnn.com/2018/06/21/europe/hungary-slovakia-polandczech-skip-migration-summit-intl/index.html [21.06.2018].

Kurekova L. (2011), Theories of migration. Conceptual review and empirical testing in the context of the EU East-West flows, paper presented at Interdisciplinary Conference on Migration. Economic Change, Social Challenge [unpublished work].

Layard R., Blanchard O., Dornbusch R., Krugman P. (1992), East-West migration. The alternatives, United Nations University Press, Cambridge, London. 
Lewis W.A. (1954), Economic development with unlimited supplies of labour, „The Manchester School", vol. 22 no. 2, pp. 139-191.

Mabogunje A.L. (1970), Systems approach to a theory of rural-urban migration, „Geographical Analysis", vol. 2 no.1, pp. 1-18.

Martin M. (2018), La llegada de inmigrantes alcanza su máximo desde 2008, „El Pais”, https://politica.elpais.com [25.06.2018].

Massey D.S., Arango J., Hugo G., Kouaouci A., Pellegrino A. (1999), Worlds in motion. Understanding international migration at the end of the millennium, Clarendon Press, Oxford.

Massey D.S., Arango J., Graeme H., Kouaouci A., Pellegrino A., Taylor J.E. (1993), Theories of international migration. A review and appraisal, „Population and Development Review”, vol. 19 no. 3 pp. 431-466.

Mezzofiore G. (2018), Italian interior minister tells rescue ship to „bring migrants to the Netherlands”, CNN, https://edition.cnn.com/2018/06/21/europe/italy-interior-minister-salvini-lifeline-rescue-shipintl/index.html [21.06.2018].

Myrdal G. (1957), The principle of circular and cumulative causation, in: Rich lands and poor. The road to world prosperity, ed. Myrdal G., Harper, New York, pp. 11-22.

Papademitrou D.G., Benton M. (2016), Towards a whole-of-society approach to receiving and settling newcomers in Europe, Migration Policy Institute, Washington DC.

Petty W. (1682), Another essay in political arithmetic, concerning the growth of the city of London. With the measures, periods, causes and consequences thereof (discourse), London, http://downloads.it.ox.ac.uk [06.12.2018]

Piore M.J. (1979), Birds of passage. Migrant labor and industrial societies, Cambridge University Press, Cambridge.

Pries L. (2013), New transnational social spaces. International migration and transnational companies in the early twenty-first century, Routledge, London.

Sassen S. (1990), The mobility of labor and capital. A study in international investment and labor flow, Cambridge University Press, Cambridge.

Shubert A., Schmidt N., Smith-Spark L. (2018), Migration „make or break” issue for Europe, warns Germany's Merkel, CNN, https://edition.cnn.com/2018/06/28/europe/eu-summit-migration-merkelintl/index.html [28.06.2018].

Silver B.J. (2003), Forces of labor. Workers' movements and globalization since 1870, Cambridge University Press, Cambridge.

Sjaastad L.A. (1962), The costs and returns of human migration, „Journal of Political Economy”, vol. 70 no. 5, Part 2, pp. 80-93.

Stark O. (1991), The migration of labor, Blackwell, Cambridge. 


\section{HUMAN MOVEMENTS: IMMIGRANTS AND ASYLUM SEEKERS.}

Stark O. (2003), Tales of migration without wage differentials. Individual, family, and community contexts, Discussion Papers, University of Bonn, Center for Development Research (ZEF), No. 18743.

The Economist (2016), Europe's scapegoat, https://www.economist.com/europe/2016/08/11/europesscapegoat [06.02.2018].

UNHCR (2018), What is a refugee?, https://www.unrefugees.org/refugee-facts/what-is-a-refugee/ [06.12.2018].

Vonberg J. (2018), Death threats, despair and deportations. Three years on the front lines of Europe's migration crisis, CNN, https://edition.cnn.com/2018/06/20/europe/world-refugee-day-volunteerseurope-intl/index.html [20.06.2018].

Vonberg J., Clarke H. (2018), Hungary's „stop Soros” law makes it illegal to help migrants, CNN, https://edition.cnn.com/2018/06/20/europe/hungary-law-immigrants-crackdown-intl/index.html [20.06.2018].

Wallace C. (1998), Migration potential in Central and Eastern Europe, International Organization for Migration, Geneva.

Zimmermann K.F. (2014), Circular migration. Why restricting labor mobility can be counterproductive, „IZA, World of Labor”, https://wol.iza.org/uploads/articles/1/pdfs/circularmigration.pdf [20.06.2018]. 